\title{
Effect of preparation practices and the cowpea cultivar Vigna unguiculata L.Walp on the quality and content of $m y o$-inositol phosphate in akara (fried bean paste)
}

\author{
Walison Fabio ROGERIO ${ }^{1}$, Ralf GREINER ${ }^{2}$, Itaciara Larroza NUNES ${ }^{1}$, \\ Sabrina FEITOSA ${ }^{1}$, Dalva Maria da Nóbrega FURTUNATOํㅜ, Deusdélia Teixeira de ALMEIDA ${ }^{1 *}$
}

\begin{abstract}
Akara is one of Brazil's national treasures prepared from cowpea (Vigna unguiculata L.Walp), grated onions and salt and deepfried in crude palm oil. The results of this study on akara preparation methods showed that, in general, cowpeas were soaked for up 3 hours at room temperature, and the seed coats were then removed. The akara makers preferred the olho de pombo cultivar, because of its cream hue, or the macassar cultivar because it produces a crispier paste. The seeds purchased from street markets had lower ranges of InsP ${ }_{6}$, InsP ${ }_{5}$ and $\operatorname{InsP}_{4}\left(1.03-7.62 \mu \mathrm{mol} . \mathrm{g}^{-1} ; 0.14-1.31 \mu \mathrm{mol} . \mathrm{g}^{-1}\right.$; and 0.0-0.10 $\mu \mathrm{mol.g} \mathrm{g}^{-1}$, respectively) than both the paste and akara $\left(6.72-19.24 \mu\right.$ mol.g ${ }^{-1} ; 1.29-4.57 \mu$ mol.g ${ }^{-1} ; 0.0-0.76 \mu$ mol.g ${ }^{-1} ; 3.31-13.71 \mu$ mol.g $\mathrm{g}^{-1} ; 0.0-4.48 \mu$ mol.g ${ }^{-1}$; and $\left.0.0-1.32 \mu \mathrm{mol} . \mathrm{g}^{-1}\right)$. These results suggest that other beans or cowpea varieties have been used in the preparation of akara and that the phytate levels do not affect its nutritional quality.
\end{abstract}

Keywords: akara; phytate; frying; biovailability; preparation techiniques.

\section{Introduction}

Originally from West Africa, akara, which is now regarded as one of Brazil's national treasures (Instituto do Patrimônio Histórico e Artístico Nacional, 2005), is a cultural and tourism icon in Salvador (Bahia, Brazil) and is sold in the streets by typically clothed women called baianas de acarajé. There are approximately 2,000 points of sale documented by the Professional Association of Baianas de Acarajé (ABAM Association of Saleswomen of Akara and Porridge). The dish is prepared with several varieties of cowpea (Vigna unguiculata L.Walp), such as fradinho, macassar, olho de pombo, costela de vaca, and boca preta. To prepare akara, the beans are split, decorticated and macerated into a paste. After being seasoned with grated onions and salt, this paste is whipped, shaped into balls with a wooden spoon, and deep-fried in crude palm oil (Instituto do Patrimônio Histórico e Artístico Nacional, 2005).

Sensory properties of cowpeas vary considerably in shape, size, and colour (Abiodun \& Adeleke, 2011; Olapade et al., 2002; Punia, 2000; Villavicencio et al., 2000). Seed coat, which is either smooth or wrinkled, can be white, cream, green, buff, red, brown, or black. They may also be speckled, mottled or blotchy. Many seeds are referred to as 'eyed' (black-eyed, pinkeyed, and purple hull) where a white hilum is surrounded by another colour (Encyclopædia Britannica Online, 2014). These colour differences have implications for cowpea products characteristics (Chinma et al., 2008).

Cowpea has a relatively low cost and high quality source of protein which is mainly cultivated in Nigeria and Brazil (Batista et al., 2010; Carvalho et al., 2012). Its nutritional value is generally reduced by antinutrients such as phytates, fibres, trypsin inhibitors, lectins, tannins, and polyphenols (Almeida et al., 2008).

Phytic acid is the hexaphosphoric ester of the hexahydric cyclic alcohol meso inositol. Phytic acid (known as inositol hexakisphosphate $\left(\operatorname{InsP}_{6}\right)$, or phytate when in salt form) is the principal storage form of phosphorus in many plant tissues. Inositol penta- $\left(\mathrm{InsP}_{5}\right)$, tetra- $\left(\mathrm{InsP}_{4}\right)$, and triphosphate $\left(\mathrm{InsP}_{3}\right)$ are also called phytates (Kumar et al., 2010). Phytate in seeds constitute 1-5\% of the weight of legumes and cereals and account for 60 to $90 \%$ of total phosphorus (Plaami, 1997). The daily intake for vegetarians is 2,000-2,600 $\mathrm{mg}$ on average, while for inhabitants of rural areas in developing countries on mixed diets it is $150-1,400 \mathrm{mg}$ (Mittal et al., 2013).

Phytate is a compound that can compromise the nutritional value because of its ability to form complexes with calcium, iron, zinc, copper, and magnesium in raw foods and in the gastrointestinal tract, thereby reducing their bioavailability (Ali et al., 2010; Davidsson \& Haskell, 2011; Konietzny \& Greiner, 2003). Phytate levels are reduced during certain food processing and preparation techniques such as baking, extrusion, fermentation, and germination (Plaami, 1997; Mensah, \& Tomkins, 2003). However, high levels of phytic acid are found in infant flour-containing cereals, infant paste-containing cereals, vegetables, legumes, and fruits (Park et al., 2006). Phytate can be partially dephosphorylated into pentakisphosphate $\left(\right.$ InsP $\left._{5}\right)$, tetrakisphosphate $\left(\right.$ InsP $\left._{4}\right)$, and trisphosphate $\left(\operatorname{InsP}_{3}\right)$ by endogenous phytases (Kumar et al., 2010).

Only the Ins $\mathrm{P}_{6}$ and $\mathrm{Ins}_{5}$ fractions can act as antinutritional factors by forming insoluble complexes with di- and trivalent

\footnotetext{
Received 18 Feb., 2014

Accepted 16 Mar., 2014 (006193)

${ }^{1}$ Escola de Nutrição, Universidade Federal da Bahia - UFBA, Salvador, BA, Brazil, e-mail: deliata@uol.com.br

${ }^{2}$ Max Rubner-Institut - MRI, Federal Research Institute of Nutrition and Food, Karlsruhe, Germany.

${ }^{*}$ Corresponding author
} 
cations, thus inhibiting cation absorption (Kumar et al., 2010). Although phytate has been widely studied for its mineral-chelating properties, it has also been investigated for its beneficial effects on diabetes mellitus, renal lithiasis, arteriosclerosis, and antioxidant action in biological systems (Kumar et al., 2010).

Previously reported data on akara comes from research on its cultural role (Instituto do Patrimônio Histórico e Artístico Nacional, 2005), chemical composition (Silva et al., 2003), and food safety (Omemu \& Aderoju, 2008). The present study was carried out to provide data on cowpea (Vigna unguiculata) selection and preparation using of akara-making by baianas de acarajé as well as data on myo-inositol phosphate content in beans, pastes, and akara.

\section{Materials and methods}

\subsection{Study site and sampling}

149 out of the 1.385 akara sales points $(11 \%)$ recorded by the Association of Baianas of Akara and Porridge (ABAM) throughout the city of Salvador, Bahia, Brazil were selected for the study. The selection process was performed in a way to guarantee that the sales points included in the study were almost equally distributed throughout the twelve regions of the city of Salvador.

Akara samples collected at each point of sale consisted of raw paste and three akara balls fried in crude palm oil which had been used for four hours (usual selling time at points). As soon as the balls were removed from the oil, they were collected, packaged in Ziploc freezer storage bags, and transported in thermal insulated boxes with ice to the laboratory where they were stored for twenty four hours at $-80{ }^{\circ} \mathrm{C}$ until they were freeze-dried (Freeze-dryer LS 3000 D, Terroni Equipamentos Científicos Ltda., Brazil).

At the moment of collection, the baiana de acarajé was invited to complete a structured questionnaire about methods of selection and preparation of cowpea used in akara (Table 1). All participants provided informed consent, which had previously been approved by the Ethics Committee of the School of Nutrition of Federal University of Bahia (Protocol 001/2008). The questions were read and completed by an interviewer in individual interviews, and the data was collected between January and March 2010. The raw seeds were purchased from local markets commonly attended by baianas in Salvador, Bahia, Brazil, under the same conditions that they are traditionally acquired and used in akara preparation. The cultivars chosen based on the most commonly used varieties by sellers: a) macassar in prepared forms of MEPT (stored, split, and with seed coats), MEPTD (stored with partially decorticated seeds) and MNPT (fresh, split, and with seed coats); b) olho de pombo, OPTD (split with seed partially decorticated); c) fradinho, FRI (whole); and d) boca preta, BPI (whole). The beans, which are either whole, mechanically split, or with seed coat partially dehulled, are sold fresh or are stored for periods that may last over one year. The seeds were sorted to remove stones, dirt, and any other foreign particles.

\subsection{Colour measurement of cowpeas}

Colour of cowpeas was measured using a Chroma Meter CR-400 (Konica Minolta Sensing Inc., Japan) and expressed in terms of lightness $\left(L^{*}\right)$, red-green characteristics $\left(a^{*}\right)$, blueyellow characteristics $\left(\mathrm{b}^{\star}\right)$, hue angle $\left(\mathrm{h}_{\mathrm{ab}}\right)$, and chroma $\left(\mathrm{C}^{\star}\right)$. The hue angle and chroma were calculated as follows: $\mathrm{h}_{\mathrm{ab}}=\tan -1$ $\left(b^{*} / a^{*}\right)$ and $C^{*}=\left[\sqrt{ }\left(a^{*}\right)^{2}+\left(b^{*}\right)^{2}\right]$. The raw cowpeas were poured homogeneously into a $500-\mathrm{mL}$ beaker, and twelve colour readings were taken at various points from the same sample at $22-24^{\circ} \mathrm{C}$ to avoid interference related to grain size and colour variations of the grain.

Table 1. Cowpea selection and preparation methods used by baianas de acarajés.

\begin{tabular}{|c|c|}
\hline Statements & $\mathrm{n}(\%)$ \\
\hline \multicolumn{2}{|l|}{ Places where the beans were purchased: } \\
\hline Supermarket & $8(5.4)$ \\
\hline Fairs & $114(76.5)$ \\
\hline Grocery store & $6(4.0)$ \\
\hline Market of akara products & $16(10.7)$ \\
\hline Others & $5(3.4)$ \\
\hline \multicolumn{2}{|l|}{ Cowpea varieties used: } \\
\hline Olho de Pombo & $33(22.1)$ \\
\hline Macassar & $42(28.2)$ \\
\hline Boca preta & $1(0.7)$ \\
\hline Fradinho & $9(6.0)$ \\
\hline Olho de pombo and/or macassar & $19(12.8)$ \\
\hline Olho de pombo or fradinho (White) & $17(11.4)$ \\
\hline Others (two or more kinds, red, soybeans) & $11(7.4)$ \\
\hline Not known & $14(9.4)$ \\
\hline \multicolumn{2}{|l|}{ Grinding of the beans: } \\
\hline Processor, manual mill, meat grinder & $18(12.1)$ \\
\hline Electric mincer & $1(0.7)$ \\
\hline Electric mill & $17(11.4)$ \\
\hline split beans & $78(52.3)$ \\
\hline Ready-to-use paste prepared at the fair & $9(6.0)$ \\
\hline Others & $23(15.4)$ \\
\hline Not known & $3(2.0)$ \\
\hline \multicolumn{2}{|l|}{ Soaking of the beans: } \\
\hline Refrigeration & $2(1.3)$ \\
\hline Room temperature & $129(86.6)$ \\
\hline Hot water & $2(1.3)$ \\
\hline Others & $2(1.3)$ \\
\hline The beans were not soaked & $14(9.4)$ \\
\hline \multicolumn{2}{|l|}{ Soaking time: } \\
\hline$<1 \mathrm{~h}$ & $30(20.1)$ \\
\hline $1-3 \mathrm{~h}$ & $91(61.1)$ \\
\hline $4-6 \mathrm{~h}$ & $9(6.0)$ \\
\hline$>6$ & $4(2.7)$ \\
\hline Not applicable ( ready-to-use paste) & $15(10.1)$ \\
\hline \multicolumn{2}{|l|}{ Removal of the seed coats: } \\
\hline Yes & $133(89.3)$ \\
\hline No & $16(10.7)$ \\
\hline
\end{tabular}




\subsection{Chemical analysis of samples}

Quantification of myo-inositol phosphates was performed in duplicate (two independent extractions per sample) in freeze-dried samples of seeds, paste, and akara by HPLC ion-pair chromatography using an Ultrasep ES 100 RP18 $(2 \times 250 \mathrm{~mm})$, as described by Greiner and Konietzny (1998). Each extraction was analyzed in duplicate. A mixture of the individual myo-inositol phosphate esters ( Ins $_{3}-\mathrm{InsP}_{6}$ ) was used as the standard.

\subsection{Data analysis}

Data analysis was performed using the SPSS 13 software (SPSS Inc, Chicago, Il, USA). Each sample was analyzed in triplicate, and the results were expressed as mean \pm standard error (SE). The bean colour and the myo-inositol phosphates in the beans were subjected to analysis of variance (ANOVA), followed by the Tukey's test to determine the differences between the means within groups. The statistically significant difference was defined as $p<0.05$. The correlation between myo-inositol phosphates in the pastes and akara was assessed by the Spearman's rank correlation test.

\section{Results and discussion}

\subsection{Cowpea selection and preparation methods used by baianas de acarajé}

According to McWatters et al. (2007), paste properties, deep-frying, and quality of akara itself are affected by the use of different cowpea varieties. Table 1 shows that baianas de acarajé choose either light hue beans (olho de pombo) or dark beans (macassar). The lighter bean varieties are more appreciated in akara preparation because they produce products of similar colour (McWatters et al., 1993). However, these beans are firmly attached to the cotyledons; therefore, they are more difficult to dehull and have the lowest swelling capacity (Olapade et al., 2002).

According to baianas de acarajé, macassar variety produces a crispier paste in comparison with other varieties. These results may be attributed to differences in composition and physical properties of the seeds. Macassar is the variety with the greatest porosity, which is a parameter that maintains a positive correlation with water uptake (Sobukola \& Abayom, 2011). Wet milling hydrated legume seed tissue yields large amounts of coarse fibrous material which can hold many times its own weight in water (Kethireddipalli et al., 2002), producing a more cohesive and elastic paste. These properties facilitate the whipping of the product, thus yielding a lighter, spongier, and crispier akara.

Sixty percent of the baianas de acarajé used a soaking time ranging between 1 and 3 hours at room temperature (86\%) (Table 1). In general, between 8 and $12 \mathrm{~h}$ were required to soak the seeds and prepare the akara (Singh et al., 2005). It is possible that the baianas de acarajé applied this short soaking time because split beans, which are used in 52\% of cases, facilitate seeds hydration, thus reducing the soaking and cooking time (Prasad et al., 2010). The seeds are wet-milled by either manual methods or electric grinders (Table 1). These processes, which have replaced the traditional grinding stones previously used by baianas, make the job easier and faster (Instituto do Patrimônio Histórico e Artístico Nacional, 2005). Even if commercial versions of cowpea bean flour were available in certain regions of Bahia, none of those interviewed reported buying prepared akara ingredients. Some studies (Abiodun \& Adeleke, 2011) have reported that akara made from commercial flour exhibits poor water absorption, is too dense, and lacks crispness compared to akara prepared with bean seeds. The smaller particle size results in heavier and less spongy akaras with rougher crusts and a lack of the characteristic flavour.

\subsection{Colour measurement of cowpeas}

The measurements with the Chroma Meter system (CIELab) showed that the boca preta, olho de pombo, and fradinho cowpea varieties were lighter $\left(\mathrm{L}^{*}\right)$ than the other varieties $(p<0.05)$; no statistically significant difference $(p>0.05)$ (Table 2$)$ was found between the boca preta and olho de pombo varieties for any of the colour measurements examined, but they were significantly different from the other beans $(p<0.05)$. The varieties boca preta and olho de pombo had a cream hue, and the macassar variety had a light brown hue (Table 2). It is worth noting that the stored macassar beans showed a higher hue angle $\left(\mathrm{h}_{\mathrm{ab}}\right)$ when compared

Table 2. Colour measurement (CIELab) and content of myo-inositol hexakisphosphate (Ins $\mathrm{P}_{6}$, phytate), myo-inositol pentakisphosphate (InsP ${ }_{5}$ ), and tetrakisphosphate $\left(\mathrm{InsP}_{4}\right)$ in raw seeds of Vigna unguiculata L. Walp.

\begin{tabular}{lrrrrrr}
\hline & \multicolumn{1}{c}{ MEPT } & \multicolumn{1}{c}{ MEPTD } & \multicolumn{1}{c}{ MNPT } & \multicolumn{1}{c}{ OPTD } & \multicolumn{1}{c}{ FRI } \\
\hline $\mathbf{L}^{*}$ & $57.45^{\mathrm{a}} \pm 0.28$ & $57.78^{\mathrm{a}} \pm 1.28$ & $55.17^{\mathrm{a}} \pm 0.58$ & $65.59^{\mathrm{b}} \pm 0.57$ & $66.90^{\mathrm{b}} \pm 0.28$ & $66.06^{\mathrm{b}} \pm 0.69$ \\
$\mathbf{a}^{*}$ & $4.90^{\mathrm{a}} \pm 0.28$ & $4.82^{\mathrm{a}} \pm 0.20$ & $7.30^{\mathrm{b}} \pm 0.49$ & $2.79^{\mathrm{c}} \pm 0.23$ & $3.52^{\mathrm{c}} \pm 0.08$ & $2.62^{\mathrm{c}} \pm 0.18$ \\
$\mathbf{b}^{*}$ & $23.01^{\mathrm{abc}} \pm 0.15$ & $23.97^{\mathrm{ab}} \pm 0.51$ & $25.22^{\mathrm{b}} \pm 0.23$ & $23.06^{\mathrm{ac}} \pm 0.15$ & $20.09^{\mathrm{d}} \pm 0.41$ & $21.91^{\mathrm{c}} \pm 0.58$ \\
$\mathbf{C}^{*}$ & $23.53^{\mathrm{ab}} \pm 0.20$ & $24.45^{\mathrm{ac}} \pm 0.54$ & $26.26^{\mathrm{c}} \pm 0.27$ & $23.22^{\mathrm{ab}} \pm 0.16$ & $20.39^{\mathrm{d}} \pm 0.42$ & $22.07^{\mathrm{bd}} \pm 0.59$ \\
$\mathbf{H}_{\mathbf{a b}}$ & $77.99^{\mathrm{a}} \pm 0.60$ & $78.63^{\mathrm{a}} \pm 0.35$ & $73.86^{\mathrm{d}} \pm 1.02$ & $83.11^{\mathrm{c}} \pm 0.54$ & $80.06^{\mathrm{a}} \pm 0.12$ & $83.20^{\mathrm{c}} \pm 0.33$ \\
\hline \multicolumn{7}{c}{ Phytate fractions $\left(\mu \mathbf{m o l}^{-1}\right.$. } \\
\hline InsP $_{\mathbf{6}}$ & $3.31 \pm 0.05$ & $7.62 \pm 0.08$ & $1.03 \pm 0.03$ & $2.67 \pm 0.15$ & $3.46 \pm 0.17$ & $1.20 \pm 0.03$ \\
InsP $_{5}$ & $0.73 \pm 0.02$ & $1.31 \pm 0.08$ & $0.14 \pm 0.01$ & $0.30 \pm 0.05$ & $0.35 \pm 0.02$ & $0.16 \pm 0.02$ \\
InsP $_{4}$ & $0.00 \pm 0.00$ & $0.10 \pm 0.03$ & $0.00 \pm 0.00$ & $0.00 \pm 0.00$ & $0.00 \pm 0.00$ & $0.00 \pm 0.00$ \\
\hline
\end{tabular}

MEPT = macassar (stored, split and with seed coats); MEPTD= macassar (stored with seed partially decorticated); MNPT = macassar (fresh, split, and with seed coats); OPTD=olho de pombo (split with seed partially decorticated), $\mathrm{FRI}=$ fradinho (whole); $\mathrm{BPI}=$ boca preta $\left(\right.$ whole). Mean \pm standard deviation. $\mathrm{L}^{*}=\mathrm{Lightness}\left(0=\mathrm{black}, 100=\right.$ white), $+\mathrm{a}^{*}=$ red, $-\mathrm{a}^{*}=$ green, $+\mathrm{b}^{*}=$ yellow, $-\mathrm{b}^{*}=$ blue, $\mathrm{H}_{\mathrm{ab}}=$ Hue angle, $\mathrm{C}^{*}=$ Chroma. Means within a row with different uppercase letters are statistically different $(\mathrm{p}<0.05)$. 
to the fresh macassar (Table 2). The darkening of cowpeas during storage is attributable to the oxidation of leucoanthocyanins catalysed by air and light although it may also be caused by non-enzymatic browning (Nasar-Abbas et al., 2009).

\subsection{Analysis of phytate content in the cowpeas, paste, and akara}

The Ins $\mathrm{P}_{6}$ and Ins $\mathrm{P}_{5}$ levels found in the raw seeds (Table 2) were comparatively lower than the ones reported for other varieties of Brazilian cowpeas (8.7-12.6 $\mu$ mol. $\mathrm{g}^{-1}$ and 1.5- $2.1 \mu \mathrm{mol.g} \mathrm{g}^{-1}$, respectively) (Almeida et al., 2008). Phytate content is a function of climatic conditions, irrigation, seed variety, and soil type (Urbano et al., 2000). Content variation may also result from the mechanical milling of the seeds sold for akara preparation (Table 1), which can cause substantial changes in the phytate content due to the removal of the aleurone layers (Bohn et al., 2008).

Table 2 shows higher values of Ins $_{6}$ and Ins $\mathrm{P}_{5}$ in the stored macassar variety compared to the same variety in a fresh state. Such results may be related to the decrease in the phytate content in the whole seed and seed coat and its increase in the cotyledon during storage (Bohn et al., 2008). It is worth noting that when cowpea seeds and/or flour are stored for a long period, they show a decrease in foam formation, hydration, and protein solubility, which are factors that may be associated with the formation of phytate-protein complexes (Bohn et al., 2008) resulting in a product of lower sensory quality (McWatters et al., 2006).
Table 3 shows the increased heterogeneity in the content of phytate both in the paste and akara. Most samples of akara and paste collected had higher levels of phytate than those of the raw seeds purchased from street sellers on with variations in time and temperature of seed maceration as well as seed types, including other varieties that were not described in this study, such as costela de vaca, feijão vermelho, and fradinho grande, as well as a mixture of cowpeas or cowpea plus soybeans (Table 1). Such diversity in preparation methods is reflected in the marketing of new versions of akara, such as 'soya akara', 'light akara', and 'zen akara' (Pires, 2008), and this diversity may partially account for the results in the present study. The mean values of InsP $\mathrm{P}_{6}, \mathrm{InsP}_{5}$, and $\mathrm{InsP}_{4}$ content in the paste (Table 3 ) represented $84.31 \%, 14.75 \%$, and $0.93 \%$, respectively, of the total content, and in the akara, $75.05 \%, 21.91 \%$, and $3.03 \%$, respectively. With regard to the inositol phosphates found in the seeds, approximately $90 \%$ is found in hexakisphosphates, and the remaining $10 \%$ account for the sum of pentakis-, tetrakis, and trisphosphates (Cúneo et al., 2000). In the fresh seeds (Table 2), the InsP $\mathrm{P}_{6}$ and InsP $\mathrm{P}_{5}$ percentages were close to the last values; however, the stored beans showed percentage values close to those found in the akara paste (Table 3).

These above mentioned results and observed correlations (Table 4) suggest that myo-inositol hexakisphosphate was dephosphorylated into pentakis- and tetrakisphosphates in the product, which may be due to high temperatures during akara frying (Mittal et al., 2013).

Table 3. Content of $m y o$-inositol hexakisphosphate $\left(\mathrm{InsP}_{6}\right.$, phytate), myo-inositol pentakisphosphate $\left(\mathrm{InsP}_{5}\right)$, and tetrakisphosphate $\left(\mathrm{InsP}_{4}\right)$ in paste and akara $\left(\mu \mathrm{mol} . \mathrm{g}^{-1}\right)$.

\begin{tabular}{|c|c|c|c|c|c|c|}
\hline & $\mathrm{N}$ & Minimum & Maximum & Mean & SE & $\%$ the total content \\
\hline Paste (InsP $\left.{ }_{6}\right)$ & 146.00 & 0.00 & 78.39 & 12.63 & 0.96 & 84.31 \\
\hline Akara (InsP $\left.{ }_{6}\right)$ & 148.00 & 0.00 & 58.09 & 7.72 & 0.69 & 75.05 \\
\hline Paste $\left(\operatorname{InsP}_{5}\right)$ & 119.00 & 0.00 & 36.18 & 2.21 & 0.33 & 14.75 \\
\hline $\operatorname{Akara}\left(\operatorname{Ins} P_{5}\right)$ & 131.00 & 0.00 & 11.05 & 1.95 & 0.17 & 21.91 \\
\hline Paste $\left(\mathrm{InsP}_{4}\right)$ & 146.00 & 0.00 & 2.36 & 0.14 & 0.04 & 0.93 \\
\hline Akara $\left(\operatorname{InsP}_{4}\right)$ & 148.00 & 0.00 & 4.34 & 0.27 & 0.05 & 3.03 \\
\hline
\end{tabular}

$\mathrm{N}=$ sample number. $\mathrm{SE}=$ Standard error.

Table 4. Spearman's correlations between the hexakisphosphate ( $\mathrm{Ins}_{6}$, phytate), myo-inositol pentakisphosphate (Ins $\mathrm{P}_{5}$ ), and tetrakisphosphate $\left(\mathrm{InsP}_{4}\right)$ in paste and akara $\left(\mu \mathrm{mol.g} \mathrm{g}^{-1}\right)$.

\begin{tabular}{|c|c|c|c|c|c|}
\hline & Akara $\left(\operatorname{InsP}_{6}\right)$ & Paste (InsP ${ }_{5}$ ) & Akara $\left(\operatorname{InsP}_{5}\right)$ & Paste (InsP $\left.{ }_{4}\right)$ & Akara $\left(\mathrm{InsP}_{4}\right)$ \\
\hline \multirow[t]{2}{*}{ Paste $\left(\mathrm{InsP}_{6}\right)$} & 0.07 & $0.547\left(^{* *}\right)$ & 0.02 & $0.223(* *)$ & -0.03 \\
\hline & 0.43 & 0.00 & 0.83 & 0.01 & 0.75 \\
\hline \multirow[t]{2}{*}{ Akara $\left(\operatorname{InsP}{ }_{6}\right)$} & & -0.15 & $\left.0.7822^{* \star}\right)$ & $0.185\left(^{*}\right)$ & $0.511\left(^{* *}\right)$ \\
\hline & & 0.12 & 0.00 & 0.03 & 0.00 \\
\hline \multirow{2}{*}{ Paste $\left(\operatorname{Ins}_{5}\right)$} & & & 0.12 & $0.382\left(^{* *}\right)$ & 0.06 \\
\hline & & & 0.23 & 0.00 & 0.55 \\
\hline \multirow[t]{2}{*}{ Akara $\left(\operatorname{InsP}_{5}\right)$} & & & & $0.240(* *)$ & $0.688\left(^{* *}\right)$ \\
\hline & & & & 0.01 & 0.00 \\
\hline \multirow[t]{2}{*}{ Paste $\left(\operatorname{InsP}_{4}\right)$} & & & & & $0.195\left(^{*}\right)$ \\
\hline & & & & & 0.02 \\
\hline
\end{tabular}

With regard to the Ins $\mathrm{P}_{6}$ the values in the first row represent Spearman's correlation ( $\mathrm{r}$ ), and the ones in the second row are the statistical significance; ${ }^{* *}$ and ${ }^{\star}$ means that correlations are significant at 0.01 and 0.05 levels, respectively. 


\section{Conclusions}

The results of this study show that the fresh variety macassar produces a akara and had the lowest content of phytate fractions, which are features that contribute to improved sensory quality and increased bioavailability of minerals in akara. When compared to the paste and end product, the lower phytate content in the seeds suggests that baianas de acarajé use different methods of paste preparation with variations in time and temperature of seed soaking as well as seed type, including other cowpea varieties and a mix of cowpeas. Additionally, other beans, such as soybeans, have been used in akara balls preparation. The high temperatures required to deep-fry the balls may have led to the lower $\mathrm{InsP}_{6}$ levels in the akara compared to those of the paste, which resulted in better nutritional values in the end product. Therefore, further studies on the influence of bean preparation methods and the physicochemical features of akara are needed.

\section{Acknowledgements}

Authors are grateful for the financial support provided by the National Counsel of Technological and Scientific Development - CNPq (Process no 482852/2007-0) and for the support from the Associação das Baianas de Acarajé e Mingau da Cidade de Salvador-Bahia-Brazil.

\section{References}

Abiodun, O. A., \& Adeleke, R. O. (2011). Effect of dehulling/soaking on the chemical, functional and anti-nutritional contents of three varieties of beans. Nutrition \& Food Science, 41(2), 117-122. http:// dx.doi.org/10.1108/00346651111117382

Ali, M., Shuja, M. N., Zahoor, M., \& Qadri, I. (2010). Phytic acid: how far have we come? African Journal of Biotechnology, 9(11), 1551-1554.

Almeida, D. T., Greiner, R., Furtunato, D. M. N., Trigueiro, I. N. S., \& Araújo, M. P. N. (2008). Content of some antinutritional factors in bean cultivars frequently consumed in Brazil. International Journal of Food Science \& Technology, 43(2), 243-249. http://dx.doi. org/10.1111/j.1365-2621.2006.01426.x

Batista, K. A., Prudêncio, S. H., \& Fernandes, K. F. (2010). Changes in the biochemical and functional properties of the extruded hard-to-cook cowpea (Vigna unguiculata L. Walp). International Journal of Food Science \& Technology, 45(4), 794-799. http://dx.doi. org/10.1111/j.1365-2621.2010.02200.x

Bohn, L., Meyer, A. S., \& Rasmussen, S. K. (2008). Phytate: impact on environment and human nutrition. A challenge for molecular breeding. Journal of Zhejiang University: Science B, 9(3), 165-191. PMid:18357620 PMCid:PMC2266880. http://dx.doi.org/10.1631/ jzus.B0710640

Carvalho, A. F. U., Souza, N. M., Farias, D. F., Rocha-Bezerra, L. C. B., Silva, R. M. P., Viana, M. P., Gouveia, S. T., Sampaio, S. S., Sousa, M. B., Lima, G. P. G., Morais, S. M., Barros, C. C., \& Freire Filho, F. R. (2012). Nutritional ranking of 30 Brazilian genotypes of cowpeas including determination of antioxidant capacity and vitamins. Journal of Food Composition and Analysis, 26(1-2), 81-88. http:// dx.doi.org/10.1016/j.jfca.2012.01.005

Chinma, C. E., Alemede, I. C., \& Emelife, I. L. G. (2008). Physiochemical and functions properties of some nigerian cowpea varieties. Pakistan Journal of Nutrition, 7(1), 186-190. http://dx.doi.org/10.3923/ pjn.2008.186.190
Cúneo, F., Amaya-Farfan, J., \& Carraro, F. (2000). Distribuição dos fitatos em farelo de arroz estabilizado e tratado com fitase exógena. Ciência e Tecnologia de Alimentos, 20(1), 94-98. http://dx.doi. org/10.1590/S0101-20612000000100018

Davidsson, L., \& Haskell, M. (2011). Bioavailability of micronutrients: stable isotope techniques to develop effective food-based strategies to combat micronutrient deficiencies. Food \& Nutrition Bulletin, 32(1), 24S-30S.

Encyclopædia Britannica Online. Cowpea. (2014). Retrieved from http://www.britannica.com/EBchecked/topic/141298/cowpea

Greiner, R., \& Konietzny, U. (1998). Endogenous phytatedegrading enzymes are responsible for phytate reduction while preparing beans (Phaseolus vulgaris). Journal of Food Processing and Preservation, 22(4), 321-331. http://dx.doi. org/10.1111/j.1745-4549.1998.tb00353.x

Instituto do Patrimônio Histórico e Artístico Nacional - IPHAN. (2005). Ofício das Baianas do Acarajé (Dossiê IPHAN 6). Brasília: Ministério da Cultura.

Kethireddipalli, P., Hung, Y. C., McWatters, K. H., \& Phillips, R. D. (2002). Effect of milling method (wet and dry) on the functional properties of cowpea (Vigna unguiculata) pastes and end product (Akara) quality. Journal of Food Science, 67(1), 48-52. http://dx.doi. org/10.1111/j.1365-2621.2002.tb11357.x

Konietzny, U., \& Greiner, R. (2003). Phytic acid: nutritional impact. In B. Caballero, L. Trugo \& P. Finglas (Eds.), Encyclopedia of Food Science and Nutrition (pp. 4555-4563). London: Elsevier. http:// dx.doi.org/10.1016/B0-12-227055-X/00923-8

Kumar, V., Sinha, A. K., Makkar, H. P. S., \& Becker, K. (2010). Dietary roles of phytate and phytase in human nutrition: a review. Food Chemistry, 120(4), 945-959. http://dx.doi.org/10.1016/j. foodchem.2009.11.052

McWatters, K. H., Chinnan, M. S., Phillips, R. D., Beuchat, L. R., Reid, L. B., \& Mensa-Wilmot, Y. M. (2006). Functional, nutritional, mycological, and akara making properties of stored cowpea meal. Journal of Food Science, 67(6), 2229-2234. http://dx.doi. org/10.1111/j.1365-2621.2002.tb09532.x

McWatters, K. H., Hung, Y. C., Chinnan, M. S., \& Phillips, R. D. (2007). Akara-making characteristics of five U. S. varieties of cowpeas (Vigna unguiculata). Journal of Food Quality, 24(1), 53-65. http:// dx.doi.org/10.1111/j.1745-4557.2001.tb00590.x

McWatters, K. H., Resurreccion, A. V. A., Fletcher, S. M., Peisher, A. V., \& Andress, E. L. (1993). Physical and sensory characteristies of akara (fried cowpea paste) made from whole and decorticated cowpeas (Vigna unguiculata). LWT - Food Science and Technology, 26(2), 157161. http://dx.doi.org/10.1006/fstl.1993.1032

Mensah, P., \& Tomkins, A. (2003). Household-level technologies to improve the availability and preparation of adequate and safe complementary foods. Food \& Nutrition Bulletin, 24(1), 104-125. PMid:12664529.

Mittal, A., Gupta, V., Singh, G., Yadav, A., \& Aggarwal, N. K. (2013). Phytase: a boom in food industry. Octa Journal of Biosciences, 1(2), 158-169.

Nasar-Abbas, S. M., Siddique, K. H. M., Plummer, J. A., White, P. F., Harris, D., Dods, K., \& D’Antuono, M. (2009). Faba bean (Vicia faba L.) seeds darken rapidly and phenolic content falls when stored at higher temperature, moisture and light intensity $L W T$ - Food Science and Technology, 42(10), 1703-1711.

Olapade, A. A., Okafor, G. I., Ozumba, A. U., \& Olatunji, O. (2002). Characterization of common Nigerian cowpea (Vigna unguiculata L. 
Walp) varieties. Journal of Food Engineering, 55(2), 101-105. http:// dx.doi.org/10.1016/S0260-8774(02)00022-5

Omemu, A. M., \& Aderoju, S. T. (2008). Food safety knowledge and practices of street food vendors in the city of Abeokuta, Nigeria. Food Control, 19(4), 396-402. http://dx.doi.org/10.1016/j. foodcont.2007.04.021

Park, H. R., Ahn, H. J., Kim, S. H., Lee, C. H., Byun, M. W., \& Lee, G. W. (2006). Determination of the phytic acid levels in infant foods using different analytical methods. Food Control, 17(9), 727-732. http://dx.doi.org/10.1016/j.foodcont.2005.05.007

Pires, I. (2008). Identidade e cultura: a baiana de acarajé como representação simbólica da Bahia. Salvador: Secretaria do Turismo. Retrieved from http://www.setur.ba.gov.br/2010/01/26/

Plaami, S. (1997). Myoinositol Phosphates: analysis, content in foods and effects in nutrition. LWT - Food Science and Technology, 30(7), 633647. http://dx.doi.org/10.1006/fstl.1997.0246

Prasad, K., Vairagar, P. R., \& Bera, M. B. (2010). Temperature dependent hydration kinetics of Cicer arietinum splits. Food Research International, 43(2), 483-488. http://dx.doi.org/10.1016/j. foodres.2009.09.038

Punia, K. P. D. (2000). Proximate composition, phytic acid, polyphenols and digestibility (in vitro) of four brown cowpea varieties. International Journal of Food Sciences and Nutrition, 51(3), 189-193. PMid:10945115. http://dx.doi.org/10.1080/09637480050029692
Silva, J. N., Miranda, K. E. S., Almeida, V. F. A., \& Benevides, C. M. J. (2003). Avaliação da composição centesimal e valor calórico de acarajés comercializados na cidade de Salvador, BA. Higiene Alimentar, 17(113), 43-45.

Singh, A., Hung, Y. C., Corredig, M., Phillips, R. D., Chinnan, M. S., \& McWatters, K. H. (2005). Effect of milling method on selected physical and functional properties of cowpea (Vigna unguiculata) paste. International Journal of Food Science \& Technology, 40(5), 525-536. http://dx.doi.org/10.1111/j.13652621.2005.00964.x

Sobukola, O. P., \& Abayom, H. T. (2011). Physical properties and rehydration characteristics of different varieties of maize (Zea mays 1.) and cowpea (Vigna unguiculata L. Walp) seeds. Journal of Food Processing and Preservation, 35(3), 299-307. http://dx.doi. org/10.1111/j.1745-4549.2009.00455.x

Urbano, G., Lopez-Jurado, M., Aranda, P., Vidal-Valverde, C., Tenorio, E., \& Porres, J. (2000). The role of phytic acid in legumes: antinutrient or beneficial function? Journal of Physiology and Biochemistry, 56(3), 283-294. PMid:11198165. http://dx.doi. org/10.1007/BF03179796

Villavicencio, A. L. C. H., Mancini-Filho, J., Delincée, H., \& Greiner, R. (2000). Effect of irradiation on anti-nutrients (total phenolics, tannins and phytate) in Brazilian beans. Radiation Physics and Chemistry, 57(3-6), 289-293. http://dx.doi.org/10.1016/S0969806X(99)00393-X 